\title{
INFLUENCE OF SOIL WATER POTENTIAL IN THE ACTION OF HERBICIDES ON GOOSEGRASS (Eleusine indica (L) Gaertn)
}

\author{
INFLUÊNCIA DO POTENCIAL DE ÁGUA NO SOLO NA AÇÃODE HERBCIDAS EM \\ CAPIM-PÉ-DE-GALINHA (Eleusine indica (L) Gaertn)
}

\author{
Maria Renata Rocha PEREIRA ${ }^{1}$; Guilherme Sasso F. de SOUZA ${ }^{2}$; José Iran Cardoso da Silva ${ }^{3}$; \\ Ana Cláudia MACEDO ${ }^{4}$; Dagoberto MARTINS ${ }^{5}$; \\ 1. Engenheira Florestal, Professora, Doutora, Faculdade de Tecnologia de Capão Bonito - FATEC, Capão Bonito, SP, Brasil. \\ mariarenatarp@ hotmail.com; 2. Engenheiro agrônomo, Doutorando, Departamento de Produção Vegetal, Faculdade de Ciências \\ Agronômicas - FCA, Universidade Estadual Paulista - UNESP, Botucatu, SP, Brasil; 3. Engenheiro agrônomo, Doutor, Pós \\ Doutorando, Universidade Federal do Tocantins, Gurupi, TO, Brasil; 4. Bióloga, Doutoranda, Departamento de Horticultura, FCA - \\ UNESP, Botucatu, SP, Brasil; 5. Engenheiro agrônomo, Professor Livre-Docente, Departamento de Produção Vegetal, Faculdade de \\ Ciências Agrárias e Veterinária - FCAV, Universidade Estadual Paulista - UNESP, Jaboticabal, SP, Brasil.
}

\begin{abstract}
Currently, the use of herbicides is essential in a practical and common in agricultural areas, but efficiency of these herbicides can be compromised when applied on plants that thrive in water deficit conditions, due to low uptake and translocation of the product. Therefore, the aim of this study was to compare the efficiency of control ACCase inhibiting herbicides applied post-emergence in plants of Eleusine indica under different soil water contents. The experiment was conducted in a greenhouse and the experimental design was completely randomized design with four replications, consisting of a $9 \times 4$ factorial, with the combination of three soil water potentials $(-0.03,-0.07$ and $-1.5 \mathrm{MPa})$ three herbicides (fluazifop-p -butyl, haloxyfop-methyl and sethoxydim + oil) and four doses (0, 25, 50, and 100\% of the recommended dose). Herbicide application was made in plants in vegetative stage 2-3 tillers. The soil water potential was initiated in the development stage of two leaves, and the water was supplemented until the soil reaches the potential of $0.01 \mathrm{MPa}$, when it came to minimum pre-determined for each water management. The physiological parameters evaluated were: photosynthetic rate, stomatal conductance, transpiration leaf temperature and plant dry mass. The visual assessments of phytotoxicity were performed at 7 and 14 days after application. The herbicides behaved in different ways according to the used water management. In severe water stress conditions (soil moisture at 8\%) only fluazifop-p-butyl herbicide achieved satisfactory control $(>90 \%)$ in E. indica plants.
\end{abstract}

KEYWORDS: Chemical control. Grass. Water restriction. Weed.

\section{INTRODUCTION}

The interference of weeds (especially the grasses) on crops can occur through competition for resources necessary for their growth, such as water, light and nutrients, as well as for the allelopathy. As the cultivated plants have already gone through improved breeding for increased productivity, they suffer most from the effects of weeds competition (FONTES, 2003), which present high photosynthesis rates in the same level of brightness, with for example in grasses, which are three times higher than that reported for beans (PORTES, 1988).

The high loss of productivity related to weed interference and the lack of alternatives for solving this problem weed competition, make herbicides as an essential practice (SANINO; GIANFREDA, 2001). To achieve greater efficiency through the use of herbicides (post-emergent) the plants should present a high metabolic activity, which may be influenced by water restriction (COBUCCI et al., 2001). Some types of stress interfere with the absorption of herbicides, for instance, high temperatures and water restriction, which can increase the cuticule of thickness, favoring the evaporation of water droplets and volatilization of applied products.

Highlighting the influence of water stress on herbicide efficiency, Pereira et al. (2012) observed minor controls in Urochloa decumbens plants in water deficit with application of ACCase inhibitor herbicides. In $E$. indica plants, the sethoxydim herbicide had their effectiveness impaired when applied to plants under water stress (PEREIRA et al., 2011).

According to Hinz and Owen (1994), in general, the deficit water stress reduces the performance of the herbicide, although the mechanisms behind this reduction are not well understood (HINZ; OWEN, 1994; BOYDSTON, 1992). On the other hand, Vallotton et al. (2003) suggest that Peganum harmala plants under optimal water conditions are less sensitive to herbicide application than those grown under severe water stress. Similar results were observed by Abbott and Sterling (2006), in which the control was not influenced by the water status of the plant, with the 
application of the hexazinone, imazapyr and metsulfuron herbicide in Peganum harmala plants. The same author notes that this relationship between water stress and performance of the herbicide is unusual, but it allows a better management of this species in stressful environments.

Drought affects the biochemistry, the physiology, the morphology and the developmental processes of plants, reducing photosynthesis in the following ways: by reducing the leaf area available to intercept solar radiation, by reducing the diffusion of $\mathrm{CO}_{2}$ into the leaf due to stomatal closure, by reducing the ability of chloroplasts to fix $\mathrm{CO}_{2}$ that enters them and wrapping and inducing leaves senescence (LEVITT, 1980; JONES, 1985, FAVER et al., 1996) and some of these factors can influence the efficiency of herbicides.

The objective of this study was to relate the efficiency of ACCase to control herbicides inhibition during post-emergence in $E$. indica plants under water stress, and to determining the soil water potential that may harm the efficiency of the herbicides and whether there are differences among the tested molecules.

\section{MATERIAL AND METHODS}

The experiment was installed and conducted at the Department of Crop Production, Agriculture Sector, Agronomic Sciences College, UNESP Botucatu, São Paulo State, Brazil, located geographically at $22^{\circ} 51^{\prime} 03^{\prime \prime}$ South latitude and $48^{\circ} 25^{\prime} 37^{\prime \prime}$ West longitude, at an altitude of $786 \mathrm{~m}$. The studies were installed from February to April 2009 with the following characterization of the climate in the greenhouse (average): minimum temperature $19.3^{\circ} \mathrm{C}$, maximum temperature $28.9^{\circ}$ $\mathrm{C}$, relative humidity $75.8 \%$ and evapotranspiration $3.1 \mathrm{~mm}$ month-1, which was daily monitored through a Class A Tank.

The used species was E. indica, grown in 2 $\mathrm{L}$ plastic pots containing soil and kept in a greenhouse. The description of soil texture was classified as average through the sieve analysis (65.6\% sand, silt $6.7,27.7$ clay).

The soil before planting was dried in air, turned over twice a week until a constant humidity of $3 \%$. To obtain the water retention curve, Richards' pressure plate was used (Klar, 1984). From the results of water retention, three minimum water potentials were established $(\Psi \mathrm{s})$ : $-0.03,-0.07$ and $-1.5 \mathrm{MPa}$, with 13,10 and $8 \%$ soil moisture, respectively, compounding the water management, evaluated by pots weighing. Upon reaching the approximation of the potential defined for each treatment, the water transpired replacement was done until reaching mass of maximum water potential of soil water retention $(-0.01 \mathrm{MPa} / 14 \%$ soil moisture). The water management strategies were initiated in the development stage of two leaves, one plant per pot.

A backpack sprayer was used, equipped with a metallic tube containing four spray nozzles of plan spray type XR11002VS, with a solution consumption of $200 \mathrm{~L} \mathrm{ha}^{-1}$.

Herbicide application was performed during the weed development of 2-3 tillers. Treatments were arranged in a $9 \times 4$ Factor; the first factor consists of nine combinations: three herbicides fluazifop-p-butyl (commercial product: Fusilade 250 $\mathrm{EW}$, recommended dose at $125 \mathrm{~g}$ i.a. ha ${ }^{-1}$ ), haloxyfop-methyl (commercial product: Verdict-R, recomended dose at $60 \mathrm{~g}$ i.a. $\mathrm{ha}^{-1}$ ) and sethoxydim (commercial product: Poast, recommended dose at $230 \mathrm{~g}$ i.a. $\mathrm{ha}^{-1}$,) and three water management strategies ( $\Psi_{\mathrm{s}}$ ) and the second factor with four doses of the products $(0,25,50$ and $100 \%$ of recommended dose).

The physiological characteristics evaluated, such as photosynthetic rate, stomatal conductance, transpiration and leaf temperature, were measured with an infrared gas analyzer (IRGA Li-6400 Licor). Evaluations were performed between 8 am and 10 am, in plants in different water managements without herbicide application. The evaluations were performed in the first fully expanded leaf of four plants per replication, totaling sixteen plants per treatment, only in plants subjected to water management because the evaluations were performed at $10 \mathrm{DAA}$ and the plants also subjected to herbicide application presented advanced symptoms of phytotoxicity, but with no possibility of admeasurement.

The effects of treatments on the plants were visually evaluated at 7 and 14 days after application depending on the species studied, using a percentage score scale in which "0" indicates no control and "100" indicates plant death (SBCPD, 1995). At the end of the evaluations, the plants were collected and dried in a forced air ventilation at $60^{\circ} \mathrm{C}$ until constant weight, and then the dry mass of the samples was determined.

The experimental design used in the studies was completely randomized with four replications. The results of physiological and phytotoxicity parameters were subjected to analysis of variance by ""F-test", and the averages were compared by Tukey test at $5 \%$ probability. 


\section{RESULTS AND DISCUSSION}

In application to the plants with 2-3 tiller stage, at 7 DAA, reduced effects provided by all herbicide were observed, even when applied at recommended dose of the product $(100 \%)$ in plants without water stress (Table 1). With the application of this dose, the highest control percentages were observed in plants grown in soil with minimum of
PEREIRA, M. R. R. et al.

$10 \%$ humidity, and the control, $74.3 \%$ higher than in plants grown in water management of $13 \%$ with the application of sethoxydim herbicide, $62.3 \%$ higher with the application of the haloxyfop-methyl herbicide, and $58.7 \%$ higher with the application of fluazifop-p-butyl herbicide. According to Maciel et al (2002), at 7 DAA of sethoxydim herbicide, crabgrass plants reached control above $80 \%$.

Table 1. Percentage of control plants of E. indica states under different water managements, 7 days after herbicide application.

\begin{tabular}{|c|c|c|c|c|c|c|}
\hline \multicolumn{2}{|c|}{ Treatment } & \multicolumn{5}{|c|}{$\%$ of herbicide dose } \\
\hline Herbicides & $\begin{array}{l}\text { Water } \\
\text { Management }\end{array}$ & 0 & 25 & \multicolumn{2}{|c|}{50} & 100 \\
\hline \multirow{3}{*}{ sethoxydim } & $13 \%$ & 0.00 a C & 13.75 cde B & 20.50 & e $A B$ & 23.75 g A \\
\hline & $10 \%$ & 0.00 a D & 18.25 bcd C & 37.50 & bc B & $92.50 \mathrm{ab} \mathrm{A}$ \\
\hline & $8 \%$ & 0.00 a C & 5.50 e C & 18.75 & e B & $65.00 \mathrm{~d} \mathrm{~A}$ \\
\hline \multirow{3}{*}{$\begin{array}{l}\text { haloxyfop- } \\
\text { methyl }\end{array}$} & $13 \%$ & 0.00 a C & 11.75 de B & 30.00 & $\operatorname{cd} \mathrm{A}$ & $32.50 \mathrm{f} \mathrm{A}$ \\
\hline & $10 \%$ & 0.00 a C & $25.00 \mathrm{ab} B$ & 25.00 & de B & 86.25 b A \\
\hline & $8 \%$ & 0.00 a C & $14.75 \mathrm{~cd} \mathrm{~B}$ & 19.25 & e B & $67.50 \mathrm{~cd} \mathrm{~A}$ \\
\hline \multirow{3}{*}{$\begin{array}{l}\text { fluazifop-p- } \\
\text { butil }\end{array}$} & $13 \%$ & 0.00 a C & $17.00 \mathrm{bcd} \mathrm{B}$ & 39.00 & b A & 41.25 e A \\
\hline & $10 \%$ & 0.00 a D & 30.75 a C & 71.50 & a B & 100.00 a A \\
\hline & $8 \%$ & $0.00 \_$a $\mathrm{D}$ & 20.50 bc $C$ & 67.00 & a B & 75.00 c $\mathrm{A}$ \\
\hline $\bar{F}_{\text {treatment }}(\bar{T})$ & \multicolumn{6}{|c|}{$155.289 * *$} \\
\hline$F_{\text {dose }}(D)$ & \multicolumn{6}{|c|}{$1986.846 * *$} \\
\hline$F(T) \times(D)$ & \multicolumn{6}{|c|}{$61.599 * *$} \\
\hline $\mathrm{CV}(\%)$ & \multicolumn{6}{|c|}{12.58} \\
\hline
\end{tabular}

Means followed by same letter in the column and capital on the line, do not differ by Tukey test (p>0.05); **: Significant at $1 \%$ probability.

Herbicides also showed better effects on plants grown in soil with minimum $8 \%$ moisture compared to those with a minimum of $13 \%$ humidity, and this difference was 45 to $64 \%$ higher in control.

Evaluating the behavior of herbicides in plants, regardless of the water management used, the best effects were seen with the applications of fluazifop-p-butyl herbicide, reaching $100 \%$ of control at 7 DAA. This behavior may be related to the greater difficulty of the herbicides on plants in optimal physiological conditions when applied late. While in plants grown with water restrictions, phytotoxic effects caused by chemicals were higher due to high weakness, along with several physiological processes entailed by water stress conditions of them. According to Maciel et al (2002), at 7 DAA of sethoxydim herbicide, crabgrass plants reached control above $80 \%$.

The effects provided by the application of $50 \%$ of the recommended herbicide dose did not differ from the effects by the application of $100 \%$ of the dose, as there were no differences among herbicides in plants without water stress. With the application of the sethoxydim and haloxyfop-methyl herbicides in plants grown under water management of $10 \%$, reductions of 60 and $71 \%$ were observed, respectively, and in plants grown in water management of $8 \%$, reductions were $71 \%$ with the application of two products.

The percentages of more satisfactory controls were found in plants with application of fluazifop-p-butyl herbicide and water management of $10 \%$ and $8 \%$, with no differences between the results obtained with these plants grown under this water management, reaching up to $71.5 \%$ of control.

The application of $25 \%$ of the recommended dose of all herbicides resulted reductions on the phytotoxicity rates on plants grown in the three water management. In treatments without water stress (water management 13\%), the greatest control reduction was observed in plants with the application of haloxyfop-methyl herbicide (63.8\%), followed by fluazifop-p-butyl herbicide $(58.8 \%)$ and sethoxydim (42.1\%), with no differences observed among the effects provided by them.

In plants grown in soil with minimum of $10 \%$ humidity, the highest control percentages were 
observed, with $30.75 \%$ and $25 \%$ with the application of fluazifop-p-butyl and haloxyfopmethyl herbicides, respectively, and they were $70 \%$ smaller compared to the application of full dose of these products and, with the application of sethoxydim herbicide, this reduction reached $80 \%$ in the control.

The effects caused by sethoxydim herbicide in plants grown in soils with minimum $8 \%$ humidity under $25 \%$ of the recommended dose were mild, with only $5.5 \%$, due to dry leaves tips. With the application of the haloxyfop-methyl and fluazifopp-butyl herbicides, control values were slightly higher compared to the other studied product, with
$14.75 \%$ and $20.5 \%$, respectively, reaching more than $70 \%$ of reduction compared to the application of $100 \%$ of the recommended dose.

The results of visual assessment of phytotoxicity at 14 days after application which were satisfactory (above 98\%) with the use of $100 \%$ of the recommended dose of all herbicides in plants subjected to water management at $10 \%$ (Table 2). Effects also satisfactory $(100 \%)$ were observed in plants under management at $13 \%$ with the use of herbicide haloxyfop-methyl, and maximum control achieved by the herbicides sethoxydim and fluazifop-p-butyl were 77.5 and $88.75 \%$, respectively.

Table 2. Percentage of control plants of E. indica states under different water managements, 14 days after herbicide application.

\begin{tabular}{|c|c|c|c|c|c|c|c|}
\hline \multicolumn{2}{|c|}{ Treatments } & \multicolumn{6}{|c|}{ Dose of herbicide (\%) } \\
\hline Herbicides & $\begin{array}{c}\text { Water } \\
\text { Management }\end{array}$ & 0 & \multicolumn{2}{|r|}{25} & 50 & \multicolumn{2}{|c|}{100} \\
\hline \multirow{3}{*}{ sethoxydim } & $13 \%$ & 0.00 a D & 37.50 & $\mathrm{bC}$ & 50.00 e B & 77.50 & e A \\
\hline & $10 \%$ & 0.00 a D & 38.75 & b C & $65.00 \mathrm{~d} \mathrm{~B}$ & 100.00 & a A \\
\hline & $8 \%$ & 0.00 a D & 32.50 & bc C & 48.75 е B & 78.80 & de A \\
\hline \multirow{4}{*}{ haloxyfop-methyl } & $13 \%$ & 0.00 a D & 63.25 & a C & 87.50 ab B & 100.00 & a A \\
\hline & $10 \%$ & 0.00 a D & 57.50 & a C & $72.75 \mathrm{~cd} \mathrm{~B}$ & 98.75 & $\mathrm{ab} A$ \\
\hline & $8 \%$ & 0.00 a D & 25.00 & $\mathrm{c} \mathrm{C}$ & 36.00 f B & 87.00 & $\operatorname{cde} \mathrm{A}$ \\
\hline & $13 \%$ & 0.00 a D & 62.50 & a $\mathrm{C}$ & 78.75 bc B & 88.75 & bcd A \\
\hline \multirow[t]{2}{*}{ fluazifop-p-butil } & $10 \%$ & 0.00 a D & 41.25 & b C & 90.25 a B & 100.00 & a A \\
\hline & $8 \%$ & 0.00 a D & 57.50 & a $C$ & 78.75 bc B & 93.50 & abc A \\
\hline $\mathrm{F}_{\text {treatment }}(\mathrm{T})$ & & & & 60.83 & & & \\
\hline$F_{\text {dose }}(D)$ & & & & $2,310$. & & & \\
\hline$F(T) \times(D)$ & & & & 15.87 & & & \\
\hline $\mathrm{CV}(\%)$ & & & & 9. & & & \\
\hline
\end{tabular}

Means followed by same letter in the column and capital on the line, do not differ by Tukey test (p>0.05); **: Significant at $1 \%$ probability.

According to Barroso et al. (2010), in a study of Urochloa decumbens, Digitaria ciliaris, Eleusine indica, Urochloa plantaginea and Cenchrus echinatus grasses, applying ACCase inhibiting herbicides, haloxyfop-methyl showed greater action spectrum.

Similar results were observed in plants exposed to water management at $8 \%$, which the herbicide sethoxydim had the lowest phytotoxicity $(78.8 \%)$. However the herbicide haloxyfop-methyl resulted in $87 \%$ control and fluazifop-p-butyl reached an average of $93 \%$ efficiency. These results suggest lower efficacy of these products, except the herbicide haloxyfop-methyl, when applied to plants without water deficit (water management at 13\%) compared to plants exposed to water management at 10 and $8 \%$, as observed at evaluations 7 DAA.
With the application of $50 \%$ of the recommended dose of all herbicides, there were reductions in the rates of phytotoxicity, regardless of the used water management. There were similar reductions in the application of herbicide sethoxydim, with $35 \%$ for plants exposed to water management at 13 and $10 \%$, and $38 \%$ for plants exposed to water management at $8 \%$, in relation to the application of $100 \%$ of the product dose. Analyzing the applying results from the low dose of this herbicide in plants growing in different water management systems, better results were observed in control of the plants grown in soil with minimum $10 \%$ humidity, which was $65 \%$ and control among the plants grown in soil with a minimum of 13 and $8 \%$ moisture did not differ, being 50 and $48.75 \%$ respectively. 
The obtained results with the application of dose $50 \%$ of herbicide fluazifop -p-butyl presented the same behavior. The control of plants grown in soil with a minimum of $10 \%$ moisture reached $90.25 \%$ (best result among all treatments), and the control among the plants grown in soil with a minimum of 13 and $8 \%$ moisture showed no differences, with $78.75 \%$. Regarding the application of $100 \%$ of the dose of this herbicide, the lowest reductions were observed, maximum of $15.8 \%$. However, the behavior of plants by applying $50 \%$ of the dose of herbicide haloxyfop-methyl was different from other used products. The highest rate of phytotoxicity was observed in plants without water stress, or kept in soil with a minimum of $13 \%$ moisture which was $87.5 \%$, followed by the results presented by the plants with water management at $10 \%$, which was $72.75 \%$. The application of $50 \%$ of the dose of herbicide provided the lowest control in plants exposed to water management at $8 \%$, among all the treatments, with $36 \%$, which represents the largest reduction $(58.6 \%)$ in relation to applications of the full dose of all studied products.

Reducing the recommended dose for $25 \%$ of the herbicides also reduced the control in all treatments, regardless of the used water management. There were no differences in control among the plants growing in different water management systems with the application of sethoxydim, averaging $36 \%$, representing a reduction compared to application of full dose, averaged $57 \%$.

No differences were observed either, in control with $25 \%$ dose of the herbicide haloxyfopmethyl applications among plants subjected to water management at 13 and $10 \%$, averaging $60 \%$. However, the control in plants subjected to water management at $8 \%$ had the worst performance among all treatments, fact also noted in the applications of $50 \%$ of the dose, reaching $25 \%$ of phytotoxicity, which represents a reduction of 71 , $3 \%$ compared to the application of $100 \%$ of the dose, whereas the reduction observed in plants subjected to the other two water managements was $39 \%$.

Different behavior was observed with the application of $50 \%$ dose of herbicide fluazifop-pbutyl, in which the major control reduction, which was $58 \%$, was observed in the plants subjected to water management at $10 \%$. There were no differences in control among plants subjected to water management at $13 \%$ and $8 \%$, averaging $60 \%$, which means a reduction of $29.6 \%$ and $38.5 \%$ respectively.
Lima and Machato-Neto (2001) found that applications of fluazifop-p-butyl herbicide with 100 $\mathrm{L}$ of syrup volume and with up to $60 \%$ reduction in dosage, were as effective as the recommended dosage in C. echinatus and E. indica plants, and for the latter, has reached over $80 \%$ at 15 DAA.

Water stress can effect on plant metabolism, leading to a loss or accumulation of metabolites such as carbohydrates, organic acids, abscisic acid (ABA) and amino acids, and alters the activity of enzymes and protein synthesis (Maranville; Paulsen, 1970). Thus, various physiological processes such as cell growth, wall synthesis, nitrogen metabolism and chlorophyll are affected and therefore also affect the accumulation of plant dry matter and may be related to the absorption and translocation of herbicides. According to Pereira et al. (2010), study with Brachiaria plantaginea noted that the control efficiency was lower plants in soil water potential of $1.5 \mathrm{Mpa}$, with the application of herbicides sethoxydim and fluazifop-p-butil.

Confirming the findings, Barroso et al. (2010) found that in application of ACCase inhibiting herbicides in E. indica plants, sethoxydim provided the worst performances of control. On the other hand, haloxyfop-methyl herbicide resulted in a control above $90 \%$. According to Vidal et al. (2006) these herbicides have different behavior according to the biotype of E. indica, in which they observed effective control with the application of sethoxydim in biotype from Rio Grande do Sul state. But in a biotype from Mato Grosso state, resistance was recorded. In this same material satisfactory control was observed with the application of haloxyfopmethyl and fluazifop-p-butyl.

These results can be explained by the fact that, despite these herbicides have the same action mechanism, they vary in the action spectrum in grasses control, as well as differences between different chemical groups (HARWOOD, 1999; OVEJERO-LÓPEZ et al., 2006). Another factor, according to Pallardy and Rhoads (1993), which can influence the absorption of herbicides by acting as a barrier, is the high cuticle resistance, namely a thick cuticle, which is an important morphological characteristics of resistance to drought, because it allows a greater water conservation in plants by reducing their loss through the epidermis (cuticular transpiration) and the ability to reduce perspiration allows plants to have better management of the water available in soil.

In plants without herbicide application, submitted to soil moisture at $13 \%$, best results of dry mass were noted (Figure 1). It was observed a reduction of $40 \%$ and $62 \%$ compared to the mass of 
the plants subjected to water management at $10 \%$ and $8 \%$, respectively. This result can be one of the factors responsible for higher phytotoxicity observed in plants without water restriction, due for instance, to increased leaf area that might have allowed greater contact with the same product. The results obtained by Herrero and Johnson (1981) and Carlesso (1993), in studies with corn, corroborate to those reported herein. These researchers demonstrated that under water deficit conditions there is a sharp decline in leaf expansion that influences the leaf roll and reducing elongation.
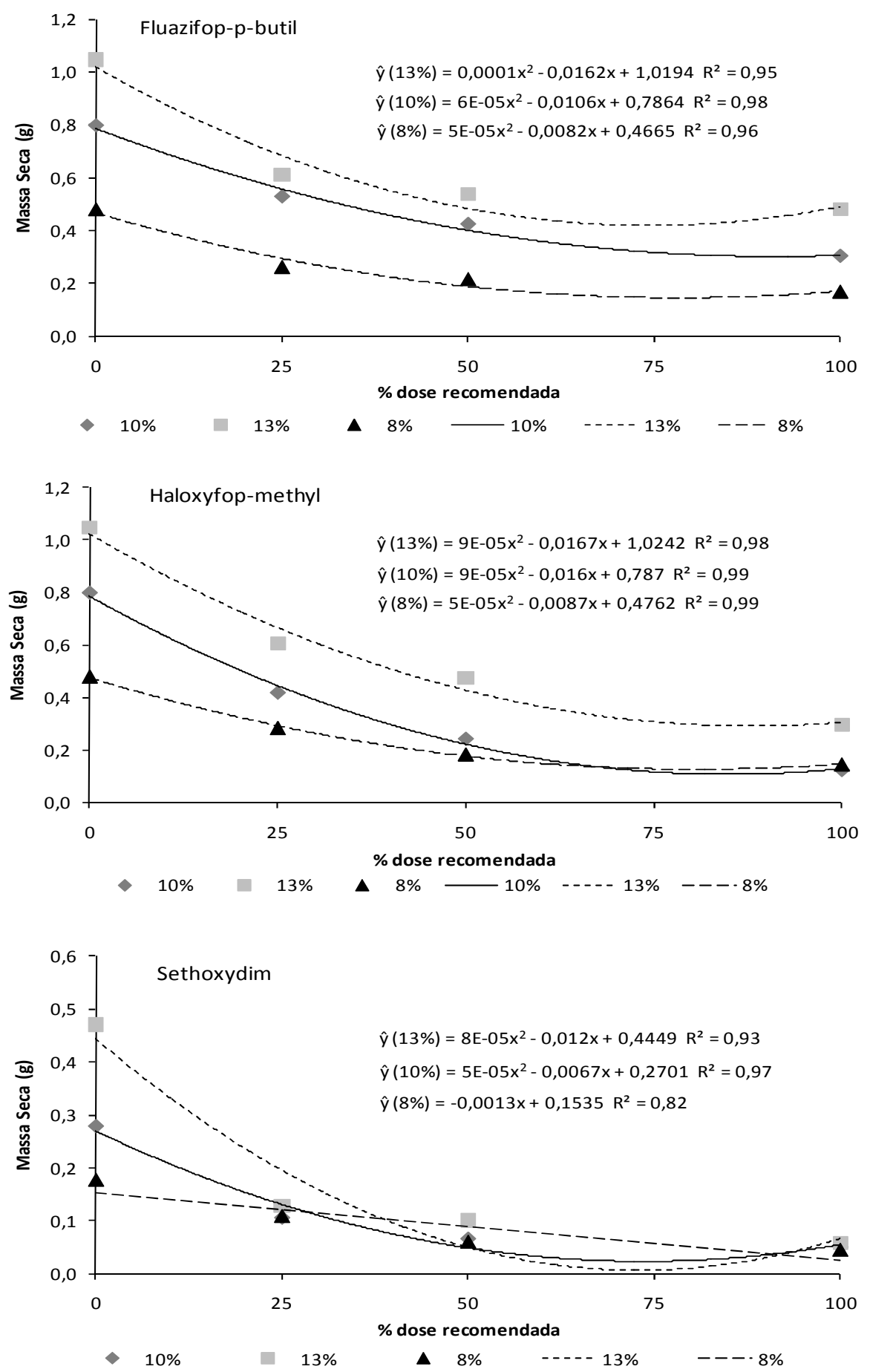

Figure 1. Dry mass of E. indica plants under different water management with application of herbicides, at four doses, after 14 days on plants at the 2-3 tiller stage. 
With the application of $100 \%$ of all herbicides dose, the greatest reductions of dry mass was observed, when compared to plants without using the products, regardless of water management used. With applications of fluazifop-p-butyl herbicide, differences were not observed between dry mass reductions of plants in different water management, and the application of $100 \%$ of the recommended dose, the decrease was in average $87 \%$ and the application of $50 \%$ of the dose, it was on average $78 \%$. However, with the application of $25 \%$ of the dose of this herbicide, the reduction of the dry mass of plants subjected to water management at $13 \%$ was $34.5 \%$, which is lower than the average reductions in dry mass of plants subject to the managements at $10 \%$ and $8 \%$, which was $71 \%$.

Similar behavior was observed with the application of haloxyfop-methyl herbicide, where the largest reductions in dry mass $(90 \%)$ were observed in plants with water management at $13 \%$ with application of $100 \%$ of the recommended dose. A small decrease in the plant dry mass reduction was noted, depending on the availability of water, with $86.6 \%$ and $84 \%$ in plants under water managements at $10 \%$ and $8 \%$, respectively.

With the reduction of the applied dose in $50 \%$, the difference of the plant dry mass without herbicide application decreases, with $83.6 \%$ of the plants without water restriction, and between plants under water managements $10 \%$ and $08 \%$ no differences were observed, with a $77.6 \%$ reduction in dry mass.

Smaller reductions were observed with the dry mass at $25 \%$ of the applied dose of haloxyfopmethyl herbicide, remaining larger for plants without water stress (water management at 13\%) which was $76.8 \%$; and $68.9 \%$ and $70.7 \%$ in the plants dry mass subjected to water management at $10 \%$ and $8 \%$, respectively.

The reduction in plants dry mass with the application of $100 \%$ and $50 \%$ of the recommended dose of sethoxydim herbicide followed the same pattern shown in other applications. There was a $87.5 \%$ reduction in plants dry mass without water stress (water management at $13 \%$ ), and $80.5 \%$ and $75 \%$ reduction in plants dry mass with water management at $10 \%$ and $8 \%$, respectively, with the application of $100 \%$ of the dose of this herbicide. This reduction decreased, according to the fractionation of the herbicide dose, with $78.6 \%$ and $72.8 \%$ reduction of plant dry mass (water management at $13 \%$ ) sprayed with $50 \%$ and $25 \%$ of the dose of the herbicide, respectively.

The plants grown in soil with minimal moisture at $10 \%$ and $8 \%$ showed dry mass reductions of $76 \%$ and $66.5 \%$ (application of $50 \%$ of the dose) and $72.8 \%$ and $39 \%$ (application of $25 \%$ of the dose) conforming the results of the latest assessment of phytotoxicity, in which there was a low percentage of control in plants exposed to water management at $8 \%$ and the application of $25 \%$ of herbicide dose.

This minor reduction in plants dry mass grown under water stress with the application of herbicides, may be related to a lower absorption and translocation of products, because when plants are exposed to situations of water stress often exhibit physiological responses as decreased production of leaf area, stomatal closure, accelerated senescence and leaf abscission (McCREE; FERNANDEZ, 1989; TAIZ; ZEIGER, 2002).

There was a significant effect of water potential in the photosynthetic rate, transpiration, stomatal conductance and leaf temperature in $E$. indica without application of herbicides (Table 3).

Table 3. Photosynthetic rate, transpiration, stomatal conductance and air temperature difference - film on plants of E. indica maintained at different soil moistures.

\begin{tabular}{|c|c|c|c|c|}
\hline $\begin{array}{c}\text { Water } \\
\text { Potentials }\end{array}$ & 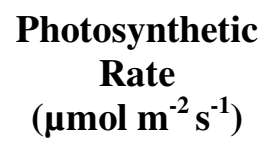 & $\begin{array}{c}\text { Transpiration } \\
\left(\mathbf{m o l}\left(\mathbf{H}_{2} \mathbf{O}\right) \mathbf{m}^{-2} \mathbf{s}^{-1}\right)\end{array}$ & 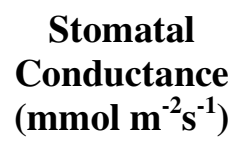 & $\begin{array}{c}\text { T leaf - T air } \\
\left({ }^{\circ} \mathrm{C}\right)\end{array}$ \\
\hline $8 \%$ & $18,9 \mathrm{c}$ & $3,08 \mathrm{c}$ & $0,1007 \mathrm{~b}$ & 3,82 a \\
\hline $10 \%$ & $23,1 \quad b$ & $3,55 \mathrm{~b}$ & $0,1327 \mathrm{~b}$ & $2,33 \mathrm{~b}$ \\
\hline $13 \%$ & 30,5 a & $4,12$. & 0,2152 a & 0,68_c \\
\hline $\mathrm{F}_{\text {treatment }}(\mathrm{T})$ & $68,642 * *$ & $29,838 * *$ & $50,052 * *$ & $18,009 * *$ \\
\hline CV (\%) & 5,82 & 5,33 & 11,16 & 32,41 \\
\hline d.m.s. & 2,794 & 0,3777 & 0,0329 & 1,4609 \\
\hline
\end{tabular}

Means followed by same letter in column do not differ by Tukey test ( $\mathrm{p}>0.05)$; **: Significant at $1 \%$ probability 
Photosynthetic rates were higher in plants grown in soil with minimum of $13 \%$ moisture. With the reduction of soil moisture also decreased photosynthetic rates. The difference among plants grown in this amount of water was on average $23 \%$ compared to plants grown in soil with minimum of $10 \%$ humidity, reaching an average increase of $40 \%$ compared to the ones maintained in soil with minimum moisture at $8 \%$, within the two evaluated stages.

Photosynthesis is closely linked to other physiological processes of plants evaluated in this study. The closing of the stomatal pore not only reduces the photosynthetic rate as well as leaf transpiration and stomatal conductance, as a way to prevent further dehydration in plants with water restriction, and decreased transpiration, among other factors, causes an increase in leaf temperature because it acts as a cooling mechanism of plants (PEREIRA et al., 2006).

The behavior of transpiration and stomatal conductance accompanied the results of photosynthetic rate, decreasing depending on the degree of water restriction imposed to the plants, within the two evaluated stages. The transpiration of plants grown in soils with water managements at $10 \%$ and $8 \%$ was on average $14 \%$ and $27 \%$ respectively, lower than in plants without water restriction (water management at 13\%). The transpiration affects the energy balance and the leaf water status, beyond the exchange of $\mathrm{CO}_{2}$ to the environment, and this fact determines the use and efficiency of water (TAIZ; ZEIGER, 2002). According to Machado et al. (1993) under water stress the plant transpiration demand is not met and therefore, the stomatal closure happens and decreased photosynthesis.

Reduced availability of water caused a $34 \%$ reduction in stomatal conductance in plants with water management at $10 \%$, reaching a reduction of up to $53 \%$ in plants with water management at $8 \%$. Corroborating these results, Pereira et al. (2003) found that irrigated corn plants presented photosynthesis and leaf conductance higher to the plants under limited water availability and these parameters showed the same pattern. The decrease in leaf conductance and transpiration with water restriction in relation to plants not stressed were similar to that reported by Kumar and Tripathi (1990) and Ritchie et al. (1990).

Stomatal closure is the primary effect, if not exclusively, of water stress on photosynthesis, as reported by Sharkey (1990), because the limited availability of water causes a decrease in leaf conductance, resulting in decreased gas exchange, thus reducing availability of $\mathrm{CO}_{2}$ to the photosynthetic apparatus, and the main route for the entry of $\mathrm{CO}_{2}$ into the leaf is through the stomata, thus, the degree of stomatal opening has a decisive effect on the entry of the same (STRZALKA; KETNER, 1997).

The water managements imposed to the plants were significant in their leaf temperature, and the treatments with reduced availability of water led to higher leaf temperatures than the ambient temperature. The difference between the ambient temperature and the leaf temperature averaged $4.0^{\circ}$ $\mathrm{C}$ in plants subjected to high water stress (water management at $8 \%$ ). This difference was reduced as there was an increase in available water for plants, which were on average $2.4^{\circ} \mathrm{C}$ in plants grown in soils with minimum of $10 \%$ moisture and only $0.60^{\circ}$ $\mathrm{C}$ in plants without any restriction of water (minimum of $13 \%$ soil moisture), which represented a reduction of over $80 \%$ of the difference between air temperature and leaf temperature compared with plants subjected to severe water stress (water management at $8 \%$ ).

The increase in leaf temperature is one of the plant responses to water stress, being the result of reduced transpiration and stomatal conductance. Researchers Taiz and Zeiger (2002) and Della Vecchia (1994) highlight the relationship between stomatal conductance and leaf temperature, because the increase in stomatal resistance decreases the conductance of it, reducing transpiration; and as this is the main form of dissipation of heat by the vegetable, this process results in increased leaf temperature. As reported by Landsberg (1986) the difference between ambient temperature and leaf temperature can be used as an indicator for the estimation of water vapor between leaf and atmosphere, and the greater the difference in water vapor, the greater the tendency to transpiration.

The results of phytotoxicity observed in this study may have been influenced by the evaluated physiological parameter due to the resistance mechanisms used by plants that affect photosynthesis in situations of water deficit (LOPEZ et al., 1988).

\section{CONCLUSIONS}

Under the conditions in which this work was done, it was concluded that with the application of fluazifop-p-butyl herbicide itself, the control was satisfactory $(>90 \%)$ in plants subjected to severe water stress ( $8 \%$ soil moisture). 
The behavior of the molecules of herbicides depends on water stress to which plants were exposed.

RESUMO: O objetivo deste estudo foi relacionar a eficiência de controle de herbicidas inibidores da ACCase aplicados em pós-emergência em plantas de Eleusine indica submetidas a diferentes teores de água no solo. O experimento foi conduzido em casa de vegetação e o delineamento experimental utilizado foi o inteiramente casualizado, com 4 repetições, constituído de um fatorial 9X4, sendo a combinação de três manejos hídricos (-0,03; -0,07 e -1,5 MPa) com três herbicidas (fluazifop-p-butil, haloxyfop-methyl e sethoxydim + óleo mineral Assist) e quatro doses destes (100, 50, 25 e $0 \%$ da dose recomendada). A aplicação dos herbicidas foi efetuada nas plantas em estádio vegetativo de 2-3 perfilhos. Os manejos hídricos foram iniciados no estádio de desenvolvimento de duas folhas, repondo-se a água até o solo atingir o potencial de $-0,01 \mathrm{MPa}$, quando este chegasse à tensão pré-determinada para cada manejo hídrico. Os parâmetros fisiológicos avaliados foram: taxa fotossintética, condutância estomática, transpiração, temperatura da folha e matéria seca das plantas. As avaliações visuais de fitotoxicidade foram realizadas aos 7 e 14 dias após a aplicação. Os herbicidas comportaram-se de maneiras distintas de acordo com o manejo hídrico utilizado. Em condições de estresse hídrico severo apenas o herbicida fluazifop-p-butyl atingiu controle satisfatório (>90\%) em plantas de E. indica submetidas à estresse hídrico severo ( $8 \%$ de umidade no solo).

PALAVRAS-CHAVE: Controle químico. Gramínea. Restrição hídrica. Planta daninha.

\section{REFERENCES}

ABBOTT, L. B., STERLING, T. M. Recovery of African rue seedlings from water stress: Implications for recruitment and invasion. African rue (Peganum harmala) seedling response to herbicides applied under waterdeficit stress. Weed Science, Lawrence, v. 54, n. 2, p. 198-204, 2006.

BARROSO, A. L. L.; DAN, H. A.; PROCÓPIO, S. O.; TOLEDO, R. E. B.; SANDANIEL, C. R.; BRAZ, G. B. P.; CRUVINEL, K. L. Eficácia de herbicidas inibidores da ACCase no controle de gramíneas em lavouras de soja. Planta daninha, Viçosa, v. 28, n. 1, p. 149-157, 2010.

BOYDSTON, R. A. Drought stress reduces fluazifop-P activity on green foxtail (Setaria viridis). Weed Science, Lawrence, v. 40, n. 1, p. 20-24, 1992.

CARLESSO, R. Influence of soil water deficits on maize growth and leaf area adjustments. Thesis. Michigan State University, East Lansing, 1993, 268 p.

COBUCCI, T.; RABELO, R. R.; SILVA, W. Manejo de plantas daninhas na cultura do arroz de terras altas na região dos cerrados. Santo Antônio de Goiás: EMBRAPA Arroz e Feijão. 60 p., 2001(Circular técnica, 42).

DELLA VECCHIA, P. T. Recomendações importantes para o cultivo com sucesso dos melões híbridos F1 comercializados pela AGROFLORA. Bragança Paulista: Sementes Agroflora S/A, 9 p., 1994.

FAVER, K. L.; GERIK, T. J.; THAXTON, P. M.; KM-El, Z. I. K. Late season water stress in cotton: Leaf gas exchange and assimilation capacity. Crop Science, Madison, v. 36, n. 4, p. 922-928, 1996.

http://dx.doi.org/10.2135/cropsci1996.0011183X003600040042x

FONTES, J. R. A. Conceito, classificação e importância das plantas daninhas. In: Fontes, J. R. A.; Shiratsuchi, L. S.; Neves, J. L.; Júlio, L.; Sodré Filho, J. Manejo integrado de plantas daninhas. Planaltina: EMBRAPA Cerrados, 8-21. 2003.

HARWOOD, J. L. Graminicides which inhibit lipid synthesis. Pesticides Outlook, Saskatoon, v. 10, n. 4, p. 154-158, 1999. 
HERRERO, M. P.; JOHNSON, R. R. Drought stress and its effects on maize reproductive systems. Agronomy Journal, Madison, v. 21, p. 105-110, 1981.

HINZ, J. R.; OWEN, M. D. K. Effect of drought stress on velvetleaf (abutilon-theophrasti) and bentazon efficacy. Weed Science, Lawrence, v. 42, n. 1, pp. 76-81, 1994.

JONES, C. A. C4 grasses and cereals: growth, development and stress response. New York: John Wiley. 419 p., 1985.

KLAR, A. E. Evapotranspiração. In: A água no sistema solo-planta-atmosfera. 2. ed. São Paulo: Brasil, 408 p., 1984.

KUMAR, A.; TRIPATHI, R. P. Relation of leaf-water potencial, diffusice resistance, transpiration rate and canopy temperature in bread wheat (Triticum aestivum). Indian Journal of Agricultural Sciences, New Delhi, v. 60 , n. 2 , p. $128-131,1990$.

LANDSBERG, J. J. Physiological ecology of forest production. London: Academic, 198 p. 1980.

LEVITT, J. Response of plants to enviropmental stress. II: Water radiation, salt and other stress. New York: Academic Press, 606 p. 1986.

LIMA, P. R. F.; MACHADO-NETO, J. G. Otimização da aplicação de fluazifop-p-butil em pós-emergência na cultura de soja (Glycine max). Planta daninha, Viçosa, v. 19, n. 1, p. 85-95, 2001.

LÓPEZ-OVEJERO, R. F.; CARVALHO, S. J. P.; NICOLAI, M.; CHRISTOFFOLETI, P. J. Suscetibilidade comparativa a herbicidas pós-emergentes de biótipos de Digitaria ciliaris resistente e suscetível aos inibidores da ACCase. Planta Daninha, Viçosa, v. 24, n. 4, p. 789-796, 2006.

LOPEZ, B. F.; SETER, T. L.; MCDAVID, C. R. Photosynthesis and water vapor exchange of pigeonpea leaves in response to water deficit and recovery. Crop Science. v. 28, n. 1, p. 141-145, 1988.

http://dx.doi.org/10.2135/cropsci1988.0011183X002800010030x

McCREE, K. J.; FERNÁNDEZ, C. J. Simulation model for studyng physiological water stress responses of whole plants. Crop Science, Madison, v. 29, n. 2, p. 353-360, 1989.

http://dx.doi.org/10.2135/cropsci1989.0011183X002900020025x

MACIEL, C. D. G.; CONSTANTIN, J.; GOTO, R. Seletividade e eficiência agronômica de herbicidas no controle de capim-colchão na cultura da melancia. Horticultura Brasileira, Brasília, v. 20, n. 3, 2002.

MACHADO, E. C.; LAGÔA, A. M. M. A.; TICELLI, R. Relações fonte-dreno em trigo submetido a deficiência hídrica no estádio reprodutivo. Revista Brasileira de Fisiologia Vegetal. São Carlos, v. 5, n. 2, p. 145-150, 1993.

MARANVILLE, J. E.; PAULSEN, G. M. Alteration of carbohydrate composition of corn (Zea mays L.) seedlings during moisture stress. Agronomy Journal, Madison, v. 62, n. 5, p. 605-608, 1970. http://dx.doi.org/10.2134/agronj1970.00021962006200050015x

PALLARDY, S. G.; RHOADS, J. L. Morphological adaptation to drought of deciduous angiosperms.

Canadian Journal Forest Research, Ottawa, v. 23, n. 9, p. 1766-1774, 1993. http://dx.doi.org/10.1139/x93-223

PEREIRA, M. R. R.; KLAR, A. E.; MARTINS, D.; SOUZA, G. S. F.; VILLALBA, J. Effect of water stress on herbicide efficiency applied to Urochloa decumbens. Ciencia e Investigación Agraria, Santiago, v. 39, n. 1, p. 211-220, 2012. http://dx.doi.org/10.4067/S0718-16202012000100018 
PEREIRA, M. R. R.; SOUZA, G. S. F.; MARTINS, D.; MELHORANÇA FILHO, A. L.; e KLAR, A. E. Respostas de plantas de Eleusine indica sob diferentes condições hídricas a herbicidas inibidores da ACCase. Planta Daninha, Viçosa, v. 29, n. 2, p. 397-404, 2011.

PEREIRA, M. R. R.; MARTINS, D.; SILVA, J. I. C.; RODRIGUES-COSTA, A. C. P.; KLAR, A. E. Efeito de herbicidas sobre plantas de Brachiaria plantaginea submetidas a estresse hídrico. Planta Daninha, Viçosa, v. 28, n. 5, p. 1047-1058, 2010.

PEREIRA, M. R. R., KLAR, A. E., SILVA, M. R., SOUZA, R. A.; FONSECA, N. R. Comportamento fisiológico e morfológico de Eucalyptus urograndis submetidos à diferentes níveis de água no solo. Irriga, Botucatu, v. 11, n. 4, p. 518-531, 2006.

PEREIRA, P. G.; BERGONCI, J. I.; BERGAMASCHI, H.; ROSA, L. M. G.; FRANÇA, S. Efeitos de diferentes níveis de déficit hídrico na fotossíntese e condutância foliar em milho. Revista Brasileira de Agrometeorologia. Santa Maria, v. 11, n. 1, p. 53-62, 2003.

PORTES, T. A. Ecofisiologia. In: ZIMMERMANN, M. J. DE O.; ROCHA, M.; YAMADA, T., Cultura do feijoeiro: fatores que afetam a produtividade. Piracicaba: POTAFOS. p. 125-156, 1988.

RITCHIE, S. W.; NGUYEN, H. T.; HOLADAY, A. S. Leaf water content and gas-exchange parameters of two wheat genotypes differing in drought resistance. Crop Science, Madison, v. 30, n. 1, p. 105-111, 1990. http://dx.doi.org/10.2135/cropsci1990.0011183X003000010025x

SANNINO, F.; GIANFREDA, L. Pesticide influence on soil enzymatic activities. Chemosphere, Oxford, v. 45, n. 4-5, p. 417-425, 2001. http://dx.doi.org/10.1016/S0045-6535(01)00045-5

SHARKEY, T. D. Water stress effects on photosynthesis. Photosynthetica, Olomouc, v. 24, n. 4, p. 651-656, 1990.

SOCIEDADE BRASILEIRA DA CIÊNCIA DAS PLANTAS DANINHAS. Procedimentos para instalação, avaliação e analise de experimentos com herbicidas. Londrina, Brasil, 42 p. 1995.

STRZALKA, K.; KETNER, P. Trocas de $\mathrm{CO}_{2}$ nas plantas. In: Prasad, M. N. V. Plant ecophysiology. New York: John Wiley. p. 393-456. 1997.

VALLOTTON, P.; PONTI, A.; WATERMAN-STORER, C. M.; SALMON, E. D.; DANUSER, G. Recovery, visualization, and analysis of actin and tubulin polymer flow in live cells: a fluorescence speckle microscopy study. Biophysical Journal, Bethesda, v. 85, n. 2, p. 1289-1306, 2003. http://dx.doi.org/10.1016/S0006-3495(03)745640

VIDAL, R. A.; PORTES, E. S.; LAMEGO, F. P.; TREZZI, M. M. Resistência de Eleusine indica aos inibidores de ACCase. Planta Daninha, Viçosa, v. 24, n. 1, p. 163-171, 2006.

TAIZ, L.; ZEIGER, E. Fisiologia vegetal. 3. ed. São Paulo: Brasil. 719 p. 2002. 